\title{
The pH Stability of Myofibrillar Adenosine Triphosphatase of Five Fiber Types in Skeletal Muscles of the Sheep and Cattle
}

\author{
Atsushi Suzuki \\ Department of Animal Science, Faculty of Agriculture, \\ Tohoku University, Sendai-shi 980
}

(Received August 22, 1975)

\begin{abstract}
The pH stability of the myofibrillar adenosine triphosphatase (ATPase) of muscle fiber types in four different skeletal muscles of the sheep and cattle was histochemically investigated. By incubating frozen sections in acid or alkaline solution before reaction for ATPase, it was found that the myofibrillar ATPase of the type A and $B$ fibers was acid-labile and alkali-stable, whereas the ATPase of the type C, D, and $E$ fibers was acid-stable and alkali-labile in both species. The ATPase activity in the $\mathrm{D}$ fibers was more strongly inhibited by preincubation at $\mathrm{pH} 4.0$ than that in the $\mathrm{C}$ and $\mathrm{E}$ fibers. Few A fibers were acid- and alkali-stable. Such $\mathrm{A}$ fibers were found in a few muscles from some animals, but not in any muscles from other animals. With the ATPase reaction after $\mathrm{pH} 4.3$ preincubation at room temperatures $\left(16-18^{\circ} \mathrm{C}\right)$, slight differences in $\mathrm{pH}$ sensitivity between the sheep and cattle were noted in the $\mathrm{B}$ fibers of a certain kind of muscles. The temperature during acid and alkaline preincubation was shown to influence the inhibition of the ATPase activity.
\end{abstract}

The ATPase reaction demonstrated by the method of PADYKuLA and HeRman ${ }^{11}$ is localized in the myofibrils and believed to be due to myosin ATPase in skeletal muscle fibers. With this reaction, the muscle fibers can be distinguished into two kinds: strongly reacting fibers and weakly reacting fibers. ${ }^{2,3)}$ Subsequently, the intensity of reaction in two kinds of fibers was shown to be reversed by immersing cryostat sections in acid solution before incubation for ATPase reaction. ${ }^{4,5}$ This has been interpreted as indicating that the myofibrillar ATPases in muscle fibers have different pH stability.

Skeletal muscle fibers of the sheep ${ }^{6-8)}$ and cattle ${ }^{9)}$ were histochemically classified into five fiber types. The type $A$ and $B$ fibers were strong in the routine ATPase activity demonstrated by the method of PAdykula and Herman, 1 1) the type $C$ and $D$ fibers weak, and the type $E$ fibers moderate. On the basis of the results of GUth and SAMAHA ${ }^{4)}$ and of BRooke and KaISER, ${ }^{51}$ the myofibrillar ATPase of the A and B fibers is assumed to be acid-labile and alkali-stable, and the ATPase of the $\mathrm{C}$ and $\mathrm{D}$ fibers is acid-stable and alkali-labile, but it is difficult to predict the $\mathrm{pH}$ stability of the myofibrillar ATPase of the $\mathrm{E}$ fibers. The present study was undertaken to investigate the $\mathrm{pH}$ sensitivity of the myofibrillar ATPase and to define the $\mathrm{pH}$ stability of it in the five fiber types of the sheep and cattle.

\section{Materials and Methods}

Muscle samples were obtained from two ewes (Corriedale), three wethers (Suffolk), two steers (Holstein) at the age of 17 months, two steers (Holstein) at the age of 20 months, and Jap. J. Zootech. Sci., 47, (2): 95-103. 
three steers (Japanese Black Cattle) at the age of 30 months. After slaughter, the samples were excised from the $M$. serratus ventralis, M. semitendinosus, $M$. longissimus thoracis, and $M$. masseter, and frozen in a mixture of dry ice and acetone. Sections $(8 \mu)$ were serially cut in a cryostat, mounted on clean glass slides, and dried at room temperature for 30 minutes.

The procedure for acid and alkaline preincubation largely followed that of BRooke and KAISER. ${ }^{5,10)}$ Acid preincubation solution was composed of $15 \mathrm{~m} l$ of MichaELis' buffer stock solution (sodium acetate $1.94 \mathrm{~g}$ + sodium barbiturate $2.94 \mathrm{~g}$ +distilled water $100 \mathrm{~m} l$ ), $30 \mathrm{~m} l$ of 0.1 $\mathrm{M} \mathrm{HCl}$, and $24 \mathrm{~m} l$ of distilled water. The $\mathrm{pH}$ was adjusted to $3.8,4.0-4.3$, and 4.6 with 0.1 $\mathrm{M} \mathrm{HCl}$. The sections were immersed in the acid solutions for 7-8 minutes. Alkaline preincubation solution was composed of $20 \mathrm{~m} l$ of $0.1 \mathrm{M}$ sodium barbiturate, $10 \mathrm{~m} l$ of $0.18 \mathrm{M} \mathrm{CaCl}_{3}$, and $70 \mathrm{~m} l$ of distilled water. The $\mathrm{pH}$ was adjusted to $9.4,10.5-10.7$, and 11.0 with $0.1 \mathrm{M} \mathrm{NaOH}$. The sections were immersed in the alkaline solutions for 26 minutes. Both the sections immersed in acid or alkaline solution were washed in the alkaline preincubation solution at $\mathrm{pH}$ 9. 4 described just above for 20 seconds. They were immediately incubated in the incubating mixture for ATPase reaction.1)

The sections preincubated in the alkaline solutions were incubated in the incubating mixture for 30 minutes, whereas the sections preincubated in the acid solutions were incubated for 45 minutes. The procedure following the incubation for ATPase reaction was the same as that of Padyula and Herman. ${ }^{1}$ " The preincubation solution and the incubating mixture were prepared immediately before use.

The acid and alkaline preincubation and the incubation for ATPase reaction were carried out at room temperatures between 16 and $18^{\circ} \mathrm{C}$ in the sections from the sheep and the 17 - and 30 -month-old steers, and at room temperatures between 23 and $25^{\circ} \mathrm{C}$ in the sections from the 20-month-old steers.

Some sections were incubated for the demonstration of the routine ATPase activity ${ }^{1}$ and used for the classification of fiber types. For the purpose of classification the activity of dihydronicotinamide adenine dinucleotide (NADH) diaphorase was demonstrated by using the method described previously. ${ }^{6}$ ) Muscle fibers were classified into five types (A, B, C, D, and E) in the same manner as reported in the previous studies. ${ }^{6-10)}$

\section{Results}

\section{Fiber types.}

In the sheep and cattle, the type A fibers reacted strongly for NADH diaphorase and the routine myofibrillar ATPase at $\mathrm{pH} 9.4$ (Figs. 3, 13). The type B fibers reacted weakly for NADH diaphorase and strongly for the myofibrillar ATPase. The type $C$ and D fibers reacted strongly for NADH diaphorase and weakly for the myofibrillar ATPase. The D fibers were larger in size than the $\mathrm{C}$ fibers, and showed the distinctive reticular pattern of diformazan in NADH diaphorase reaction (Figs. 3, 13). The type E fibers reacted very strongly for NADH diaphorase and moderately for, the myofibrillar ATPase (Fig. 9).

2. The sensitivity of myofibrillar ATPase to the $\mathrm{pH}$ of preincubation solution in each fiber type.

Preincubation at room temperatures between 16 and $18^{\circ} \mathrm{C}$ : The myofibrillar ATPase activity of the $\mathrm{A}$ and $\mathrm{B}$ fibers in ovine and bovine muscles was very strong after preincubation at the $\mathrm{pH}$ between 9.4 and 10.7, and moderate to strong at pH 4.6 (Figs. 1, 3-8, 13-20). After pre- 


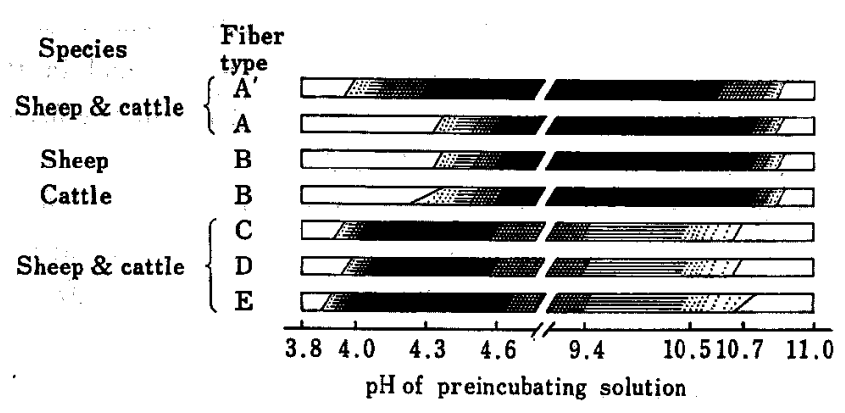

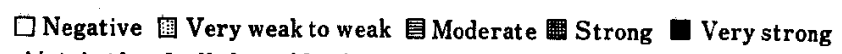
$A^{\prime}$ : Acid-and alkali-stable $A$ fiber

Fig. 1. The pH sensitivity of myofibrillar ATPase reaction in muscle fiber types of the sheep and cattle at room temperatures of $16 \sim 18^{\circ} \mathrm{C}$

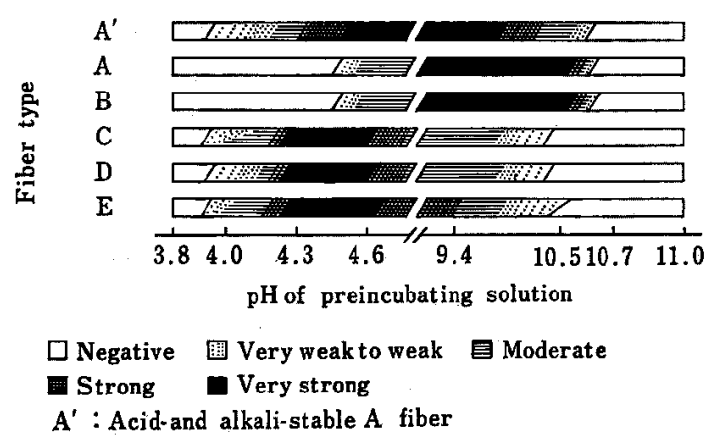

Fig. 2. The pH sensitivity of myofibrillar ATPase reaction in bovine muscle fiber types at room temperatures of $23 \sim 25^{\circ} \mathrm{C}$

incubation at $\mathrm{pH} 4.3$, the ATPase reaction was negative in the $\mathrm{A}$ fibers of both species and in the B fibers of ovine muscles and the bovine $M$. serratus ventralis (Figs. 1, 3, 7, 13-18), whereas the $\mathrm{B}$ fibers of the bovine $M$. longissimus thoracis and $M$. semitendinosus reacted negatively to weakly for the ATPase (Figs. 1, 19-22). The negatively reacting $B$ fibers were fewer than the weakly reacting $B$ fibers in these muscles and were $8.9-12.5 \%$ of the $B$ fibers $(0.47-5.0 \%$ of the total fibers). The weakly reacting $B$ fibers were completely inhibited by preincubation at a $\mathrm{pH}$ below 4.2 .

The ATPase activity of the $\mathrm{C}$ and $\mathrm{D}$ fibers in both species was very strong after preincubation at $\mathrm{pH} 4.3$ and 4.6, moderate to strong at $\mathrm{pH} 9.4$, weak to moderate at $\mathrm{pH} 10.5$, and negative at $\mathrm{pH}$ 10.7. At $\mathrm{pH} 4.0$ preincubation the activity was moderate to strong in the $\mathrm{C}$ fibers and weak to moderate in the $\mathrm{D}$ fibers; the latters were more lightly stained than the formers (Figs. 1, 3-8, 13-18). The ATPase activity of the $\mathrm{E}$ fibers in both species was very

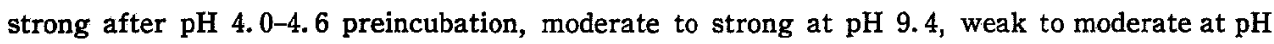
10.5 , and negative to very. weak at $\mathrm{pH} 10.7$ (Figs. $1,9-12$ ).

Some fibers reacted strongly to very strongly for the ATPase after preincubation at the $\mathrm{pH}$ between 4.3 and 10.7 and weakly at $\mathrm{pH} 4.0$ (Figs. 1, 16-18). They reacted strongly for

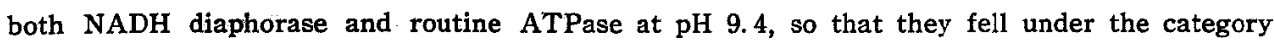


of the A fibers and were expressed as the acid- and alkali-stable $\mathrm{A}$ fibers for convenience sake.

In one of the sheep, the acid- and alkali-stable A fibers were found in the $M$. semitendinosus $(3.1 \%$ of the A fibers, $1.0 \%$ of the total fibers), but not in the $M$. serratus ventralis nor in the $M$. longissimus thoracis. Nor were these fibers seen in three kinds of muscles from other sheep. Such A fibers were none to very few $(0-2.0 \%$ of the $A$ fibers, $0-0.4 \%$ of the total fibers) in these muscles from the 30 -month-old steers. In the 17 -month-old steers, they were $18.8-24.1 \%$ of the A fibers (4.6-4.9\% of the total fibers) in the $M$. serratus ventralis, but none to very few $(0-0.7 \%$ of the A fibers, $0-0.1 \%$ of the total fibers) in the M. longissimus thoracis and $M$. semitendinosus.

The myofibrillar ATPase reaction of all the fiber types in both species was completely inhibited by preincubation at $\mathrm{pH} 3.8$ and $\mathrm{pH} 11.0$.

Preincubation at room temperatures between 23 and $25^{\circ} \mathrm{C}$ : In the 20 -month-old steers, the $\mathrm{A}$ and $\mathrm{B}$ fibers were negative in the ATPase reaction after preincubation at $\mathrm{pH} 4.3$, moderate at $\mathrm{pH} 4.6$, and very strong at $\mathrm{pH} 9.4$ and 10.5 (Fig. 2). With the reaction after $\mathrm{pH} 4.6$ preincubation, the A fibers were stained slightly more lightly than the $\mathrm{B}$ fibers in the $M$. longissimus thoracis and $M$. semitendinosus, but no difference in staining intensity between the $\mathrm{A}$ and B fibers was seen in the $M$. serratus ventralis. The acid- and alkali-stable A fibers were weak in the reaction after preincubation at $\mathrm{pH} 4.0$, moderate at $\mathrm{pH} 4.3$ and 10.5 , and very strong at $\mathrm{pH} 4.6$ and 9.4. They were found only in the $M$. serratus ventralis from one of two steers and $8.6 \%$ of the $\mathrm{A}$ fibers (1.3\% of the total fibers):

The $\mathrm{C}$ fibers of the $M$. longissimus thoracis and $M$. semitendinosus and the $\mathrm{D}$ fibers were weak in the reaction after preincubation at $\mathrm{pH} 4.0$, whereas the $\mathrm{C}$ fibers of the $M$. serratus ventralis were moderate. The $\mathrm{C}$ and $\mathrm{D}$ fibers reacted very strongly for the ATPase after $\mathrm{pH}$ 4. 3-4.6 preincubation and moderately at $\mathrm{pH} 9.4$ preincubation. The $\mathrm{E}$ fibers were weak to moderate in the reaction after preincubation at $\mathrm{pH} 4.0$, very strong at $\mathrm{pH} 4.3$ and 4.6 , and moderate to strong at $\mathrm{pH}$ 9.4. The reaction of the $\mathrm{C}, \mathrm{D}$, and $\mathrm{E}$ fibers was negative after $\mathrm{pH}$ 10.5 preincubation. The ATPase reaction of all the fiber types was completely inhibited by preincubation at $\mathrm{pH} 3.8$ and a $\mathrm{pH}$ above 10.7 .

\section{Discussion}

The results of the ATPase reactions after acid and alkaline preincubation revealed that the myofibrillar ATPase of the $E$ fibers as well as the $C$ and D fibers was acid-stable and alkali-labile, whereas the ATPase of the $A$ and $B$ fibers was acid-labile and alkali-stable. In the sheep, the muscle fibers that showed a positive reaction for $\beta$-hydroxybutyrate dehydrogenase and were liable to develop fatty change in starvation ${ }^{11,12)}$ proved to be the fibers having the acid-stable and alkali-labile ATPase.

The acid- and alkali-stable $A$ fibers found in bovine and ovine muscles resembled the type IIC fibers of BrooKE and KAISER. ${ }^{10)}$ BRooKeET et al. have suggested that the type IIC fibers are the primitive fibers and differentiated into both type IIA fibers and type IIB fibers during development. ${ }^{18}$. The type IIA and IIB fibers resemble the type $A$ and $B$ fibers of bovine and ovine muscles, respectively. It is therefore presumed that the acid- and alkali-stable A fibers have the nature similar to that of the type IIC fibers, and that they may be transformed into the acid-labile and alkali-stable fibers in the animal kept for a longer period, because they were fewer in the 20- and 30-month-old steers than in the 17-month-old steers and rarely observed in the muscles of the adult sheep. Accordingly, the difference in proportion of the acid- and 
alkali-stable $A$ fibers is not assumed to represent the difference between breeds and between species.

With the ATPase reaction after $\mathrm{pH} 4.3$ preincubation at $16-18^{\circ} \mathrm{C}$, large numbers of the $\mathrm{B}$ fibers in the $M$. longissimus thoracis and $M$. semitendinosus of the cattle were weakly positive. The weakly positive B fibers were not seen in the same muscles of the sheep, nor in the $M$. serratus ventralis of the cattle. These facts indicate that the $\mathrm{pH}$ sensitivity of the myofibrillar ATPase slightly differs between the cattle and sheep and among different muscles of the same animal.

During the preincubation in alkaline solution and the incubation in the mixture for ATPase reaction, the sections are liable to loosen and crumple. Although fixation can prevent the sections from loosening or crumpling, myofibrillar ATPase is sensitive to fixatives, ${ }^{2,8,14}$, When the sections from rat muscles are fixed in buffered formalin before alkaline preincubation, the formaldehyde-sensitive and the formaldehyde-resistant fibers were observed.4) In addition, the formalin fixation has variable effects on a particular fiber type in different species. ${ }^{16}$ ) In this study, the sections were not fixed with any fixative in order to avoid the influence of fixation on the myofibrillar ATPase reactions. The results obtained may not always be in agreement with the reactivity in the sections fixed with formalin before incubation.

On the other hand, the sections preincubated in acid solution little loosen or crumple during the following incubation. Accordingly, satisfactory results in staining are easier to be obtained. Instead, however, of the reaction after alkaline preincubation or the routine ATPase reaction, the ATPase reaction after acid preincubation is unsuitable to use for the classification of fiber types, because the acid- and alkali-stable $A$ fibers are regarded as the $\mathrm{C}$ fibers by mistake.

The ATPase reaction after preincubation at $\mathrm{pH} 4.0$ and $\mathrm{pH} 10.7$ was inhibited more strongly in room temperatures between 23 and $25^{\circ} \mathrm{C}$ than in those between 16 and $18^{\circ} \mathrm{C}$. This indicates that the temperature during acid and alkaline preincubation influences the inhibition of the ATPase reaction. KHAN et al, have shown that the specific temperature of acidic and alkaline preincubation bath is a major contributing factor in the histochemical demonstration of myosin ATPase. ${ }^{16)}$

The $\mathrm{pH}$ of preincubation solution and the duration of preincubation very greatly influence the following ATPase reaction.4) Moreover, this reactivity in muscle fibers under the same condition differs among different species. ${ }^{10,16}$. If the same pattern or intensity of the staining in the ATPase reactions is to be obtained among various muscles of different species, the $\mathrm{pH}$ and duration of preincubation must be modified to some extent. In addition, the sections need to be preincubated at a selected, constant temperature.

This study was supported in part by Grant-in-Aid for Scientific Research from the Ministry of Education.

The author is greatly indebted to Dr. M. OKADA of National Grassland Research Institute and to Mr. S. TANaka of Chugoku National Agricultural Experimental Station for providing the materials of the cattle, and to Mr. S. OHWADA for assistance in collecting the samples.

\section{References}

1) Padykula, H. A., and E. Herman, J Histochem Cytochem 3: 170-195. 1955.

2) Stein, J.M., and H. A. Padykula, Amer J Anat 110: 103-115. 1962. 


\section{SuzUKI}

3) Padykula, H. A., and G.F. Gauthirk, J Cell Biol 18: 87-107. 1963.

4) Gurh, L., and F. J. Samaha, Exp Neurol 25: 138-152. 1969.

5) Brooke, M. H., and K. K. KAISER, J Histochem Cytochem 18: 670-672, 1970.

6) Suzukı, A., Jap J Zootech Sci 42: 39-54. 1971.

7) SuzukI, A., Jap J Zootech Sci 42: 463-473. 1971.

8) Suzuki, A., Jap J Zootech Sci 43: 161-166. 1972.

9) Suzuki, A., and H. Tamate, Acta Histochem Cytochem 7: 319-327. 1974.

10) Brooke, M.H., and K. K. KaISER, Arch Neurol 23: 369-379. 1970.

11) Suzuki, A., Jap J Zootech Sci 44: 258-265. 1973.

12) Suzuki, A., Jap J Zootech Sci 45: 401-407. 1974.

13) Brooke, M.H., E. Wrlliamson, and K. K. Kajser, Arch Neurol 25: 360-366. 1971.

14) Wachstein, M., E. Meisel, and A. Niedzwiedz, J Histochem Cytochem 8: 387-388: 1960 .

15) Yellin, H., and L. Guth, Exp Neurol 26: 424-432. 1970.

16) Khan, M. A., J. M. Papadimitriou, and B. A. Kakulas, Histochemistry 38: 181-194. 1974,

\section{Explanation of Figures}

Figs. 3-8. The $M$. serratus ventralis of the sheep. A, B, C, and D indicate the type $A, B, C$, and $D$ fibers, respectively. X 280. Fig. 3. NADH diaphorase: Fig. 4. ATPase preincubated at $\mathrm{pH}$ 9.4. Fig. 5. ATPase preincubated at $\mathrm{pH}$ 10.7. Fig. 6. ATPase preincubated at $\mathrm{pH}$ 4.6. Fig. 7. ATPase preincubated at pH 4.3. Fig. 8. ATPase preincubated at pH 4.0.

Figs. 9-12. The $M$. masseter of the sheep. $E$ indicates the type $E$ fibers. X 280. Fig. 9. NADH diaphorase. Fig. 10. ATPase preincubated at pH 9.4. Fig. 11. ATPase preincubated at $\mathrm{pH}$ 10.7. Fig. 12. ATPase preincubated at $\mathrm{pH}$ 4.0.

Figs. 13-15. The M. serratus ventralis of the 30-month-old cattle. Fig. 13. NADH diaphorase. Fig. 14. ATPase preincubated at pH 10.7. Fig. 15. ATPase preincubated at pH 4.3.

Figs. 16-18. The $M$. serratus ventralis of the 17-month-old cattle. Arrows indicate the acidr. and alkali-stable A fibers. X 280. Fig. 16. NADH diaphorase. Fig. 17. ATPasé preincubated at $\mathrm{pH} 10.7$. Fig. 18. ATPase preincubated at $\mathrm{pH} 4.3$.

Figs. 19 and 20. The $M$. semitendinosus of the sheep. $\mathrm{X} 280$.

Fig. 19. NADH diaphorase. Fig. 20. ATPase preincubated at pH 4.3.

Figs. 21 and 22 . The $M$. semitendinosus of the cattle. $\mathrm{X} 280$.

Fig. 21. NADH diaphorase. Fig. 22. ATPase preincubated at pH 4.3. 
pH Stability of Myofibrillar ATPase

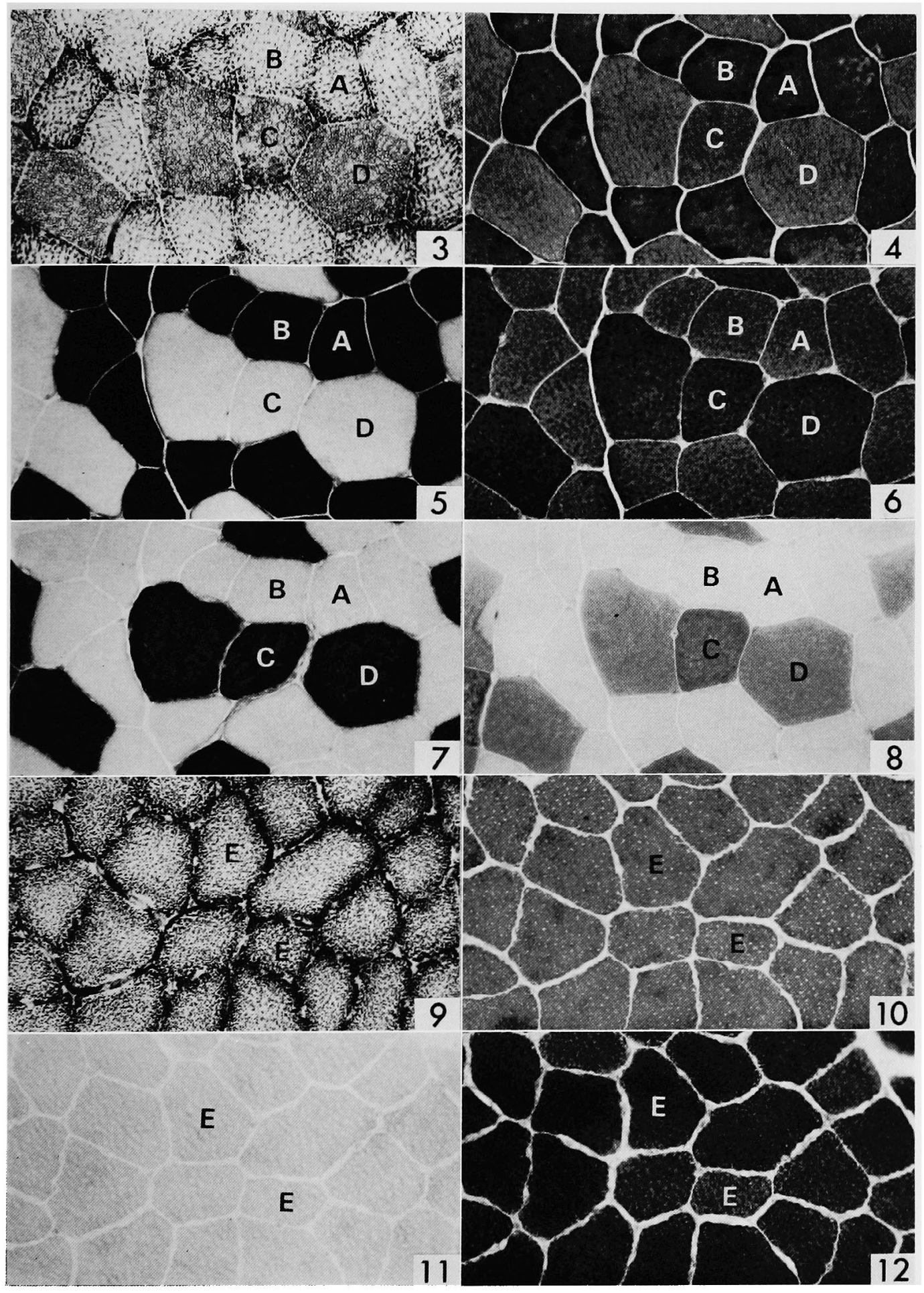




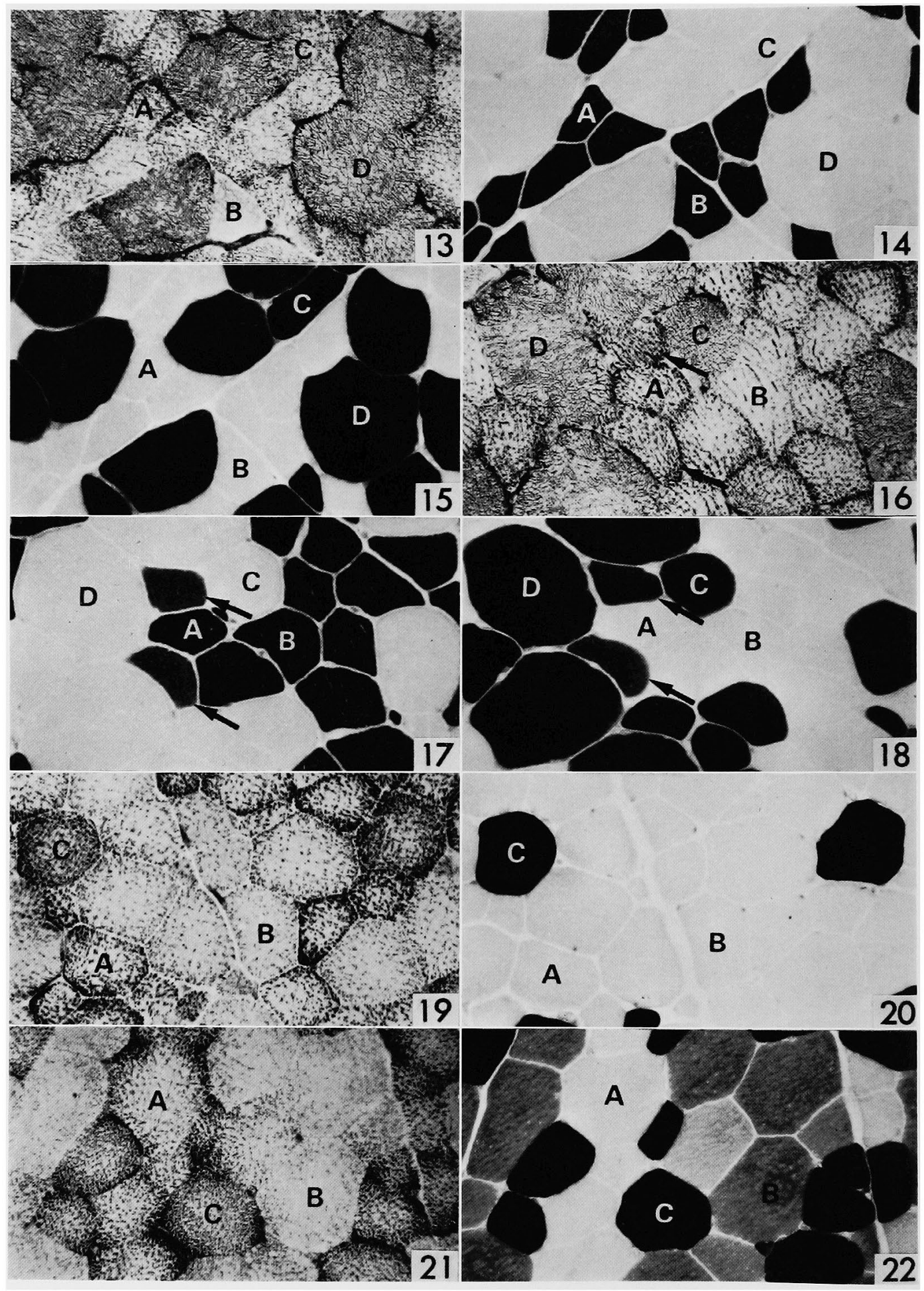




\title{
メン羊と牛の骨格筋の 5 種類の筋線維型における myofibrillar adenosine triphosphatase $の \mathrm{pH}$ 安定性について
}

\author{
鈴木 憞 \\ 東北大学農学部，仙台市 980
}

メン羊と牛の骨格筋の筋線維型における myofibrillar ATPase の.pH 安定性帘組織化学的に調べた，クリオス タット切片を ATPase の反応の前に, 酸およびてルカ リの溶液に浸漬することにより，これらの動物のA型と B型筋線維の myofibrillar ATPase 4 , 酸不安定 フルカリ安定性であり，C型，D型， E型筋線維のそれ は，酸安定・フルカリ不安定性であることがわかった． pH4.0 の前処理で，D型筋線維の ATPase 活性は，C 型
および $\mathrm{E}$ 型筋線維よりも強く抑制された。酸およびアル カリ安定性のA型筋線維が見つかったが，その数は少な く，個々の筋肉执よび個体ではないものむあった. 室温 $\left(16 \sim 18^{\circ} \mathrm{C}\right)$ で pH 4.3 の前処理後の ATPase 反応で は,めん羊と牛の間で $\mathrm{pH}$ に対する感受性のわずかな差 が，ある種の笳肉のB型筋線維でみられた。酸およびて ルカリ前好理における温度は，このATPase 活性の抑 制に影隦を及ぼすことが示された。 